\title{
OPTIMAL VOLTAGE PROFILE FOR HEMISPHERICAL DEFLECTOR ENERGY ANALYZERS USING GENETIC ALGORITHM
}

\author{
Nimet IŞIK \\ Mathematics and Science Education Department, Burdur Mehmet Akif Ersoy University, Turkey, \\ nokumus@mehmetakif.edu.tr, \\ iD https://orcid.org/0000-0002-1347-6628
}

Received: 01.02.2018, Accepted: 01.06.2018

*Corresponding author

Research Article

\section{Abstract}

In this study, the genetic algorithm (GA) method is used to optimize the hemispherical deflector analyzer, which can analyze according to the energies of charged particles. The GA inspired by evolutionary codes consists of the population of individuals. At each step, the GA, selects the population individuals as parents and uses them to produce children for the next generation. Thus throughout generations, the population evolves to an optimal solution. The purpose of this study is to achieve the best voltage profile for the $180^{\circ}$ hemispherical energy analyzers through the voltage equations of the energy analyzer. The best voltage values for the $180^{\circ}$ hemispherical deflector analyzer, which is the most used analyzer in experimental studies, are found with high accuracy in this study. Optimization of a complex electron optical system, such as an analyzer system with a GA, has been achieved using voltage equations and has been found to work very well given the difficulty of the problem. In contrast to other techniques in the literature, the best voltage profile is obtained in a short time by means of the proposed GA method.

Keywords: Electron optics, electrostatic energy analyzer, artificial intelligence, genetic algorithm, optimization.

\section{YARI KÜRESEL SAPTIRICI ENERJİ ANALİÖRLERİ ICÇIN GENETIKK ALGORITTMA ÍLE EN IYYI VOLTAJ PROFILİ}

\section{Öz}

Bu çalışmada, yüklü parçacıkların enerjisine göre analizini gerçekleştirebilen, yarı küresel saptırıcı analizörünü optimize etmek için genetik algoritma (GA) yöntemi kullanılmıştır. Evrim kodlarından esinlenen GA, bireyler popülasyonundan oluşmaktadır. Her adımda, GA, popülasyon bireylerini ebeveyn olarak seçip bu bireyleri gelecek nesil için çocukları üretmek için kullanır. Böylece kuşaklar boyunca, nüfus en iyi bir çözüme doğru gelişmektedir. Bu çalışmanın amacı, enerji analizörüne ait voltaj denklemleri aracılığılla, $180^{\circ}$ yarı küresel enerji analizörleri için en iyi voltaj profilini elde etmektir. Deneysel çalışmalarda en çok kullanılan analizör olan $180^{\circ}$ yarı küresel saptırıcı analizörü için en iyi voltaj değerleri yüksek doğrulukla bu çalışmada bulunmuştur. GA ile analizör sistemi gibi karmaşı kir elektron optiksel sistemin optimizasyonu, voltaj denklemleri kullanılarak elde edilmiştir ve problemin zorluğu göz önüne alındığında oldukça iyi çalıştı̆̆ı bulunmuştur. Literatürde yer alan diğer tekniklerin aksine, önerilen GA yöntemi aracılığıla, en iyi voltaj profili kısa sürede elde edilmektedir.

Anahtar Kelimeler: Elektron optiği, elektrostatik enerji analizörü, yapay zeka, genetik algoritma, optimizasyon.

Cite

Işık N., (2018). “Optimal Voltage Profile for Hemispherical Deflector Energy Analyzers Using Genetic Algorithm”, Mugla Journal of Science and Technology, 4(1), 74-78.

\section{Introduction}

The need to develop energy analyzers with high energy resolution has stimulated different methods to obtain their optimum voltages. The energy analyzer commonly used in experimental systems is the $180^{\circ}$ hemispherical deflector analyzer (HDA) [1]. This analyzer consists of two hemispheres, including inner and outer hemispheres. The operating voltage ranges of these hemispheres determine the energy resolution of the charged particle beam moving in the electric field generated by the hemispheres. For this reason, it is vitally important to determine the optimum operating voltages before experimental studies.
The charged particles moving in an ideal field of hemispheres follows the Keplerian orbit [2]. This situation causes high energy resolution and high transmission. However, this situation changes when working in the laboratory environment. In the laboratory environment, the pure ideal field is often deteriorated by the mounting plate of the analyzer [3]. Late last five decades, conventional approaches have been proposed to solve this problem. The main ones are the application of Herzog [4] and Jost correctors [5]. In addition to these applications, it has been proposed to apply tilted input lenses mounted on the entrance and exit of the hemispheres [6]. In addition to these studies, it is shown by Benis and Zouros that the fringing field effect is corrected by a small displacement from the central position of the analyzer entrance for the charged particle beam [7]. In parallel with this practice, 
analyzes for paracentric entry analyzers is expanded in Ref. [3, 8-12). Although these studies in the literature are successful, artificial neural networks (ANN) inspired by the biological neural system architecture is an effective and practical method to obtain the trajectories of electron beam in the HDA [13]. It has been shown that the ANN algorithm trained with an appropriate dataset predicts an unknown data with high accuracy.

Of special interest in this study are the investigation optimum voltages of the centric and paracentric entry HDA using the genetic algorithm (GA). GA is a search and optimization technique that inspired by evolution. It is a population-based and stochastic algorithm based on en-coded parameters of the solution to a problem. It is advisable to solve a series of problems that have the objective function [14]. GA assesses objective function which is to be optimized by choosing random points of the definition domain [15]. Moreover, GAs can provide solutions for highly complex search spaces for all types of problems such as more field-specific algorithm [16]. For example, some application fields of GA in physics are optimization of an irreversible radiative-type heat engine [17], structural optimization of Lennard-Jones clusters [18], lithiumion battery model optimization [19] and molecular geometry optimization of an atomic cluster [20], In this study, the GA is used effectively to optimize voltage values of the inner and outer hemispheres of the $180^{\circ}$ hemispherical deflector energy analyzers over a wide range of parameters.

This study consists of three basic parts: Section 2.1 includes the basic consideration of positively and negatively paracentric entry HDA and centric entry HDA. In section 2.2, the basic components of the genetic algorithm are explained. Section 3 gives the results of the mathematical model termed as GA for voltage ratios of hemispheres in the HDAs.

\section{Material and Method \\ 2.1. Centric and Paracentric Entry HDA}

The hemispherical deflector analyzer is shown schematically in figure 1. Basically, an HDA consists of two concentric hemispheres. These hemispheres considered here have radii $\mathrm{R}_{1}=85 \mathrm{~mm}$. and $\mathrm{R}_{2}=115 \mathrm{~mm}$. with an analyzer center at 0 . These inner and outer hemispherical electrodes are held at the potentials $V_{1}$ and $V_{2}$, respectively (Fig. 1). The incoming electrons which have been focused at the entrance plane of the hemispheres by the input optics pass around the analyzer. Electrons of desired energy have been only transported to the detector. These electrons trace a circular path due to the appropriate voltages applied to the hemispheres. These electron trajectories are shown in the red color in Fig. 1.

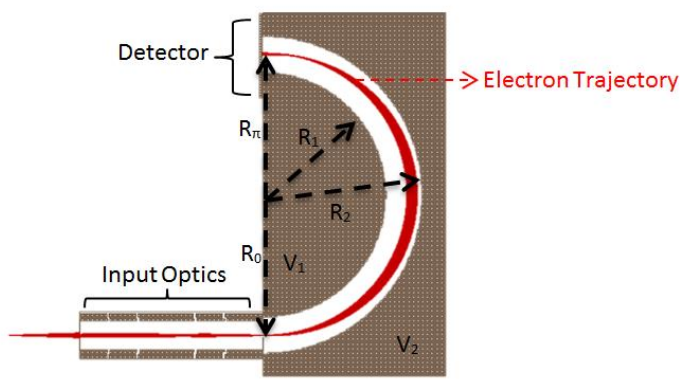

Figure 1. Schematic cross section of the $180^{\circ}$ hemispherical deflector analyzer. A particle with desired energy follows the trajectory shown in red color.

The electrode potentials in an ideal $1 / \mathrm{r}$ potential is given by
$\mathrm{qV}_{\mathrm{i}}=\mathrm{E}_{0}\left\{1-\frac{\gamma}{\xi}\left[\frac{\mathrm{R}_{0}(1+\xi)}{\mathrm{R}_{\mathrm{i}}}-1\right]\right\} \quad(\mathrm{i}=1,2)$

where $\xi$ is the HDA paracentricity (equals to $R_{\pi} / R_{0}$ ) and $\gamma$ stands for the biasing parameter.

\subsection{Genetic Algorithm (GA)}

GA method inspired by evolution is used to find optimal solution for the target problem [23]. For this context, GA has been used for optimization, search and selection problems such as area layout problems [24], land grading computations [25], and task scheduling problem [26], dynamic clustering problem [27], performance enhancement problems [28] and distribution network optimization [29].

Basically, the steps of the GA are shown in Fig. 2 as a flowchart. In a first step, chromosomes are created randomly to form the initial population. Secondly, the compliance value is calculated by objective function for each chromosome in the population. In the third step, selection, crossover and mutation operators are applied for new populations. After this calculation, the fitness values are calculated for each solution chromosome in the new population being created as a fourth step. In the last step, third and fourth steps are repeated until the stop condition is obtained. When algorithm is stopped, the most appropriate sequence is chosen as the solution $[21,30]$.

Genetic algorithm generally includes the selection of a population of sequences, the application of crossover and mutation operators. After the implementation of these operators, a new population is formed. In the next step, the new population is replaced by the old population [21]. The new population is selected according to these compliance values. In each newly produced population, attempts are made to produce more compatible new population [22].

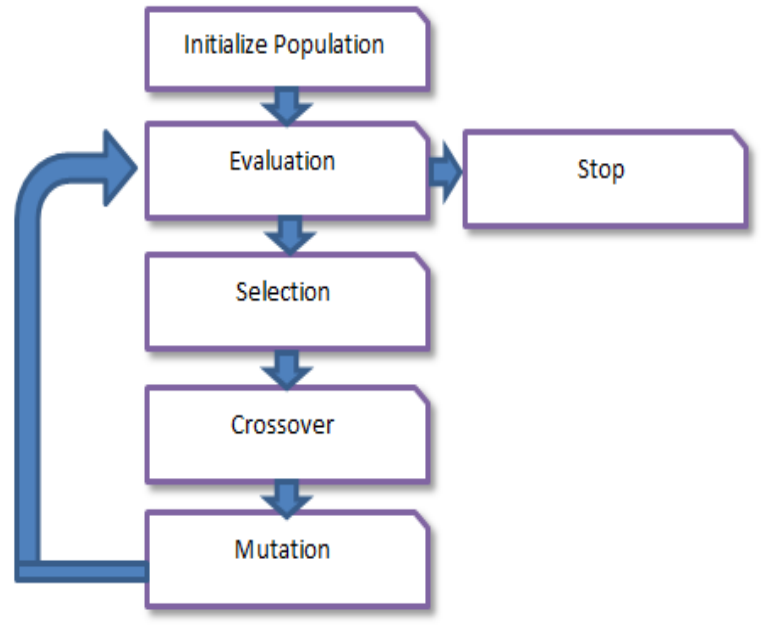

Figure 2. Flow chart of genetic algorithm.

\section{Results}

The GA proposed in this study is used to find optimal voltage results using Equation 1 for both positively and negatively biased paracentric entries HDA. In this context, the genetic algorithm calculation was carried out step by step. Firstly, the initial population was generated. $V_{i}, \xi, \gamma$, and $R_{0}$ are variables in equation (1) for an ideal field HDA. They are encoded as a chromosome with real numbers according to the boundaries, as shown in Figure 3. In this encoding, each chromosome is regarded as a solution $S_{1}$ to $S_{n}$ where $n$ is population size. $S_{1} G_{1}$ to $S_{n} G_{1}$ are genes that represent $V_{i}, S_{1} G_{2}$ to $S_{n} G_{2}$ are genes that 
represent $\xi, S_{1} G_{3}$ to $S_{n} G_{3}$ are genes that represent $\gamma, S_{1} G_{4}$ to $S_{n} G_{4}$ are genes that represent $R_{0}$.

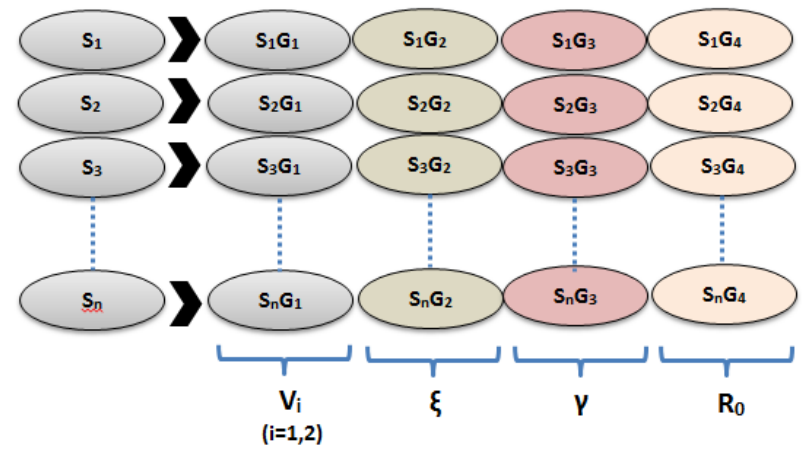

Figure 3. Encoded chromosomes for optimization of paracentric entry HDA equation.

In Equation 1, $\mathrm{E}_{0}$ was taken as a constant value of $500 \mathrm{eV}$. Therefore, the fitness function which is to be minimized was founded as:

$\mathrm{F}(\mathrm{x})=\frac{\mathrm{qV}_{\mathrm{i}}}{\left\{1-\frac{\gamma}{\xi}\left[\frac{\mathrm{R}_{0}(1+\xi)}{\mathrm{R}_{\mathrm{i}}}-1\right]\right\}}-500$

where $q=-1, R_{i}=85$ for $i=1$ and $R_{i}=115$ for $i=2$. The initial chromosome population was calculated according to the $\mathrm{F}(\mathrm{x})$ fitness function. Then, the best chromosomes that minimize $\mathrm{F}(\mathrm{x})$ were selected to the new population using election rate. As a next step in the calculation, new chromosomes were regenerated and mutated by mutation rate. In this study, same GA parameters were used both the calculations for the positively and negatively biased paracentric entry HDA equation. Population size was taken as 300 , mutation rate was taken as 0.25 , election rate was 0.1 , and maximum generation count $(\varepsilon)$ was taken as 1000 . When maximum generation count $(\varepsilon)$ is reached, GA is finished. Therefore, the best chromosome in last population was shown as optimal voltage result for both positively and negatively biased paracentric entry HDA.

The calculations were performed using Equation (1) according to $\gamma>1, \xi>1$ and $R_{0}<R_{\text {mean }}$ values. $R_{0}$ was taken at values between 85 and $100 \mathrm{~mm}$. while $\mathrm{E}_{0}=500 \mathrm{eV}$ was taken at a constant value. $\gamma$ and $\xi$ are between 1 to 1.5 for positively biased paracentric HDA. For this context, optimum voltage values of inner hemispheres $\left(V_{1}\right)$ as a function of the values $R_{0}$ and $\xi$ for $\gamma=1$ are given in figure 4 . In addition to, optimum voltage values of inner hemispheres $\left(\mathrm{V}_{1}\right)$ for $\gamma=1.5$ are given in figure 5 . Optimum voltage values of outer hemispheres $\left(\mathrm{V}_{2}\right)$ as a function of the values $\mathrm{R}_{0}$ and $\xi$ for $\gamma=1$ are given in figure 6 . In addition to, optimum voltage values of outer hemispheres $\left(V_{2}\right)$ for $\gamma=1.5$ are given in figure 7 .

The computational results were also obtained using genetic algorithm software for the negatively biased paracentric entry HDA, according to the values of $\gamma<1, \xi<1$ and $R_{0}>R_{\text {mean. }}$. $R_{0}$ was taken at values between 100 and $115 \mathrm{~mm}$. while $\mathrm{E}_{0}=500 \mathrm{eV}$ was taken at a constant value. $\gamma$ and $\xi$ are between 0,5 to 1 for negatively biased paracentric HDA. For this context, optimum voltage values of inner hemispheres $\left(\mathrm{V}_{1}\right)$ as a function of the values $R_{0}$ and $\xi$ for $\gamma=0.7$ were given in figure 8 . In addition to this calculation results, optimum voltage values of outer hemispheres $\left(V_{2}\right)$ for $\gamma=0.7$ were given in figure 9. Considering the results, the GA gives the analyzer parameter values over a wide range of operation.

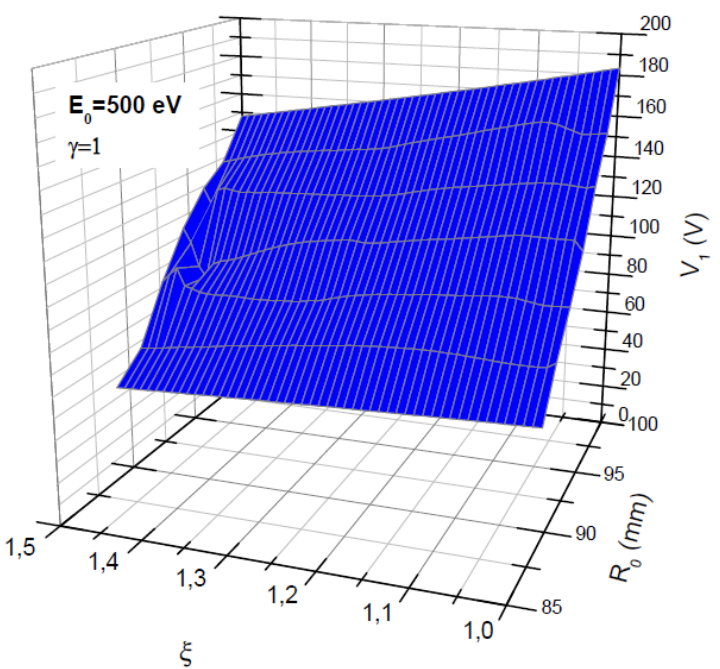

Figure 4: Optimum voltage values of inner hemispheres $\left(\mathrm{V}_{1}\right)$ as a function of the values $\mathrm{R}_{0}$ and $\xi$ for $\mathrm{E}_{0}=500 \mathrm{eV}$ and for $\gamma=1$.

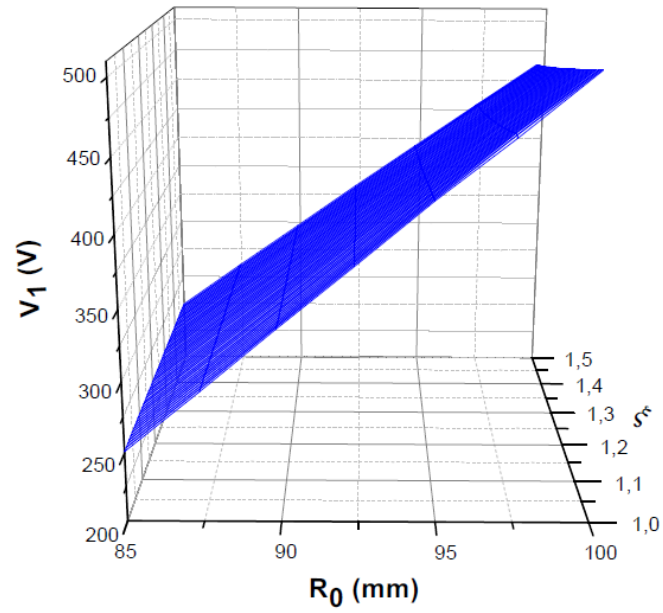

Figure 5: Optimum voltage values of inner hemispheres $\left(\mathrm{V}_{1}\right)$ as a function of the values $\mathrm{R}_{0}$ and $\xi$ for $\mathrm{E}_{0}=500 \mathrm{eV}$ and for $\gamma=1,5$.

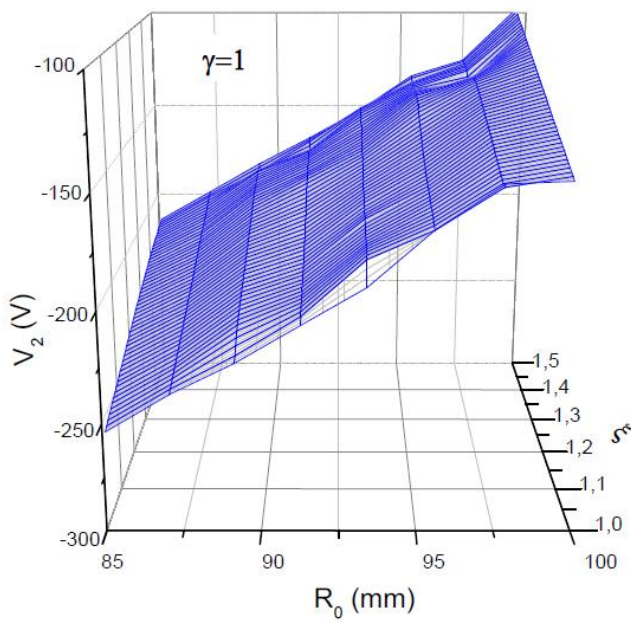

Figure 6: Optimum voltage values of outer hemispheres $\left(V_{2}\right)$ as a function of the values $\mathrm{R}_{0}$ and $\xi$ for $\mathrm{E}_{0}=500 \mathrm{eV}$ and for $\gamma=1$. 


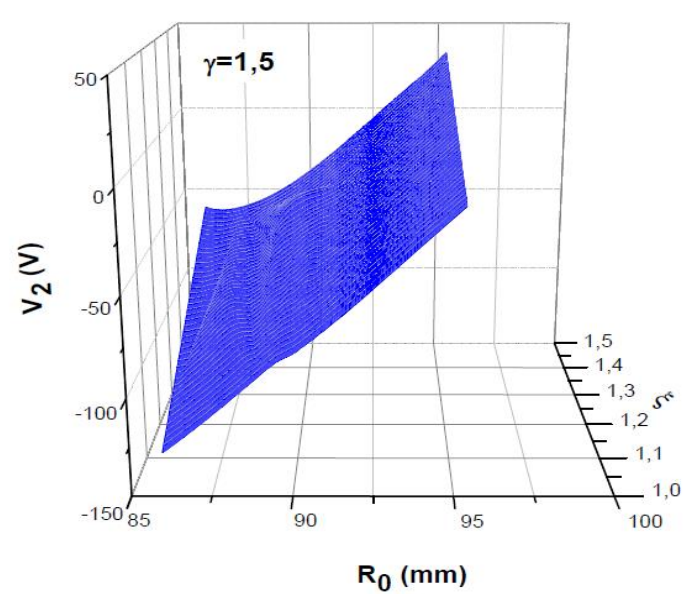

Figure 7: Optimum voltage values of outer hemispheres $\left(\mathrm{V}_{2}\right)$ as a function of the values $\mathrm{R}_{0}$ and $\xi$ for $\mathrm{E}_{0}=500 \mathrm{eV}$ and for $\gamma=1,5$.

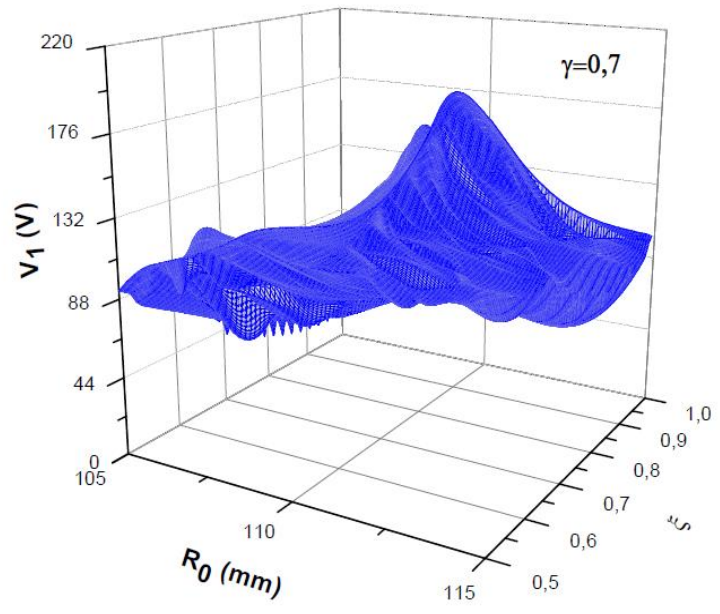

Figure 8: Optimum voltage values of inner hemispheres $\left(\mathrm{V}_{1}\right)$ as a function of the values $\mathrm{R}_{0}$ and $\xi$ for $\mathrm{E}_{0}=500 \mathrm{eV}$ and for $\gamma=0,7$.

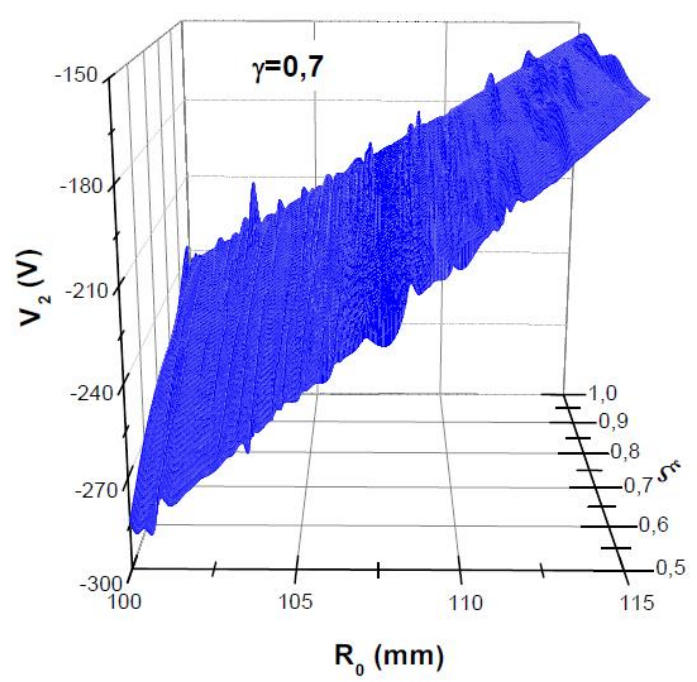

Figure 9: Optimum voltage values of outer hemispheres $\left(V_{2}\right)$ as a function of the values $\mathrm{R}_{0}$ and $\xi$ for $\mathrm{E}_{0}=500 \mathrm{eV}$ and for $\gamma=0,7$.

\section{Conclusions}

We have computed the voltage values of the inner and outer hemispheres of the $180^{\circ}$ hemispherical deflector energy analyzers over a wide range of parameters. These calculations were carried out with GA as an innovative method. GA is the heuristic search and optimization technique that mimics the process of natural evolution. Therefore, the generated algorithm is started with a series of solutions (represented by chromosomes) called populations. A new population was created by taking solutions from this population. This is repeated until the best solution is achieved. In the study, binary coding, which is the most common coding method in genetic algorithm, is used. In this code, just like on a chromosome, each gene controls a specific feature of the individual. The results have been presented in threedimensional graphical form. The evolutionary computing based GA technique iss advantageous in experimental studies in terms of giving solution results for a large number of parameters. According to the results of this study, the genetic algorithm produces a fast and efficient solution for determining optimum voltages of hemispherical deflector energy analyzers.

\section{Acknowledgment}

I would like to thank Dr. Murat Ince for his valuable suggestions during the planning and development of this study.

\section{References}

[1] Imhof R. E., Adams A., King G. C., "Energy and Time Resolution of the 180 Degrees Hemispherical Electrostatic Analyzer", Journal of Physics E: Scientific Instruments, Vol. 9, No.2, pp. 138-142. 1976.

[2] Heddle D.W.O., Electrostatic Lens Systems, CRC Press, United Kingdom. 2000.

[3] Sise O., Ulu M., Dogan M., Martinez G., Zouros T. J. M., "Fringing Field Optimization of Hemispherical Deflector Analyzers Using BEM and FDM", J. Elect. Spect. Rel. Phen., Vol. 177, No. 1, pp. 42-51, 2010.

[4] R. Herzog, "Ablenkung von Kathoden- und Kanalstrahlen am Rande eines Kondensators, dessen Streufeld durch eine Blende begrenzt ist", Z. Physik, Vol. 97, pp. 596-602, 1935.

[5] K. Jost, "Fringing field correction for 127 degrees and 180 degrees electron spectrometers", J. Phys. E: Sci. Instrum., Vol. 12, pp. 1001, 1979.

[6] N. Martensson, "A Very High Resolution Electron Spectrometer", J. Electron Spectrosc. Relat. Phenom., Vol. 70, pp. 117-128, 1994.

[7] E.P. Benis, T.J.M. Zouros, "Improving the Energy Resolution of a Hemispherical Spectrograph Using a Paracentric Entry at a Non-zero Potential", Nucl. Instrum. Meth. Phys. Res. A, Vol. 440, pp. 462-465, 2000.

[8] T.J.M. Zouros, E.P. Benis, "The Hemispherical Deflector Analyser Revisited. I. Motion in the Ideal 1/r Potential, Generalized Entry Conditions, Kepler Orbits and Spectrometer Basic Equation", J. Electron Spectrosc. Relat. Phenom. Vol. 125, pp. 221-248, ibid. Vol. 142 (2005) 175176, 2002.

[9] T.J.M. Zouros, O. Sise, M. Ulu, M. Dogan, "DESIGN NOTE: Using the fringing fields of a hemispherical spectrograph to improve its energy resolution", Meas. Sci. Technol. 17, 2006, pp. N81-N86, 2006.

[10] 0. Sise, T.J.M. Zouros, M. Ulu, M. Dogan, "Novel and traditional fringing field correction schemes for the hemispherical analyser: Comparison of first-order focusing and energy resolution", Meas. Sci. Technol., Vol. 18, pp.1853-1858, 2007. 
[11] B.P. Benis, T.J.M. Zouros, "The Hemispherical Deflector Analyser Revisited II. Electron-Optical Properties",J. Electron Spectrosc. Relat. Phenom., Vol. 163, pp.28-39, 2008.

[12] Sise O., Zouros T. J. M., Position, Energy, and Transit Time Distributions in a Hemispherical Deflector Analyzer with Position Sensitive Detector, J. Spect., Vol. 1535, pp. 13-20, 2015.

[13] Işık N., Işık A.H., Sise O., Guvenc U., "Prediction of First Order Focusing Properties of Ideal Hemispherical Deflector Analyzer Using Artificial Neural Network" Vol. 131, No. 1, pp. 10-12, 2017.

[14] Goldberg D. E., Holland, J. H., "Genetic Algorithms and Machine Learning", Mach Learn., Vol. 3, No.2, pp. 95-99, 1988.

[15] Bashir L. Z., "Solve Simple Linear Equation using Evolutionary Algorithm", World Sci. News, Vol.19, pp. 148167, 2015.

[16] Bashir L. Z., Mahdi, N., "Use Genetic Algorithm in Optimization Function for Solving Queens Problem". World Sci. News, Vol. 11, pp.138-150, 2015.

[17] Ahmadi M. H., Ahmadi M. A., , "Thermodynamic Analysis and Optimisation of an Irreversible Radiative-Type Heat Engine by Using Non-dominated Sorting Genetic Algorithm, Int. J. Ambient Energy, Vol. 37, No. 4, pp. 403408, 2016.

[18] Deaven D. M., Tit N., Morris J. R., Ho K. M., "Structural optimization of Lennard-Jones Clusters by a Genetic Algorithm", Chem. Phys. Lett., Vol. 256, No. 1-2, pp. 195200, 1996.

[19] Zhang L., Wang L., Hinds G., Lyu C., Zheng J., Li J., "MultiObjective Optimization of Lithium-Ion Battery Model Using Genetic Algorithm Approach", J. Power Sources, Vol. 270, pp. 367-378, 2014.

[20] Deaven D. M., Ho K. M., "Molecular Geometry Optimization with a Genetic Algorithm", Phys. Rev. Let., Vol. 75, No. 2, pp.288, 1995.

[21] Goldberg D.E., "Genetic Algorithms in Search Optimization and Machine Learning, Addison Wesley Press, Boston, USA, 1989.

[22] Jang J.S.R., “Neuro-Fuzzy and Soft Computing: A Computational Approach to Learning and Machine Intelligence, Chapter 7: Derivative-Free Optimization", Prentice-Hall Press, USA, 1997.

[23] Wang Y. Z., "Using Genetic Algorithm Methods to Solve Course Scheduling Problems", Expert Syst. Appl., Vol. 25, No. 1, pp. 39-50, 2003.

[24] Paes F. G., Pessoa A. A., Vidal T., "A Hybrid Genetic Algorithm with Decomposition Phases for the Unequal Area Facility Layout Problem", Eur. J. Oper. Res., Vol. 256, No.3, pp. 742-756, 2017.

[25] Raeisi-Vanani H., Shayannejad M., Soltani-Toudeshki A. R., Arab M. A., Eslamian S., Amoushahi-Khouzani M., OstadAli-Askari K., "A Simple Method for Land Grading Computations and its Comparison with Genetic Algorithm (GA) Method", Int. Res. Stud. Agric Sci., Vol. 3, No. 8, pp. 2638, 2017.

[26] Keshanchi B., Souri A., Navimipour N. J., "An Improved Genetic Algorithm for Task Scheduling in the Cloud Environments Using the Priority Queues: Formal
Verification, Simulation, and Statistical Testing”, J. Syst. Softw., Vol. 124, pp. 1-21, 2017.

[27] Yuan X., Elhoseny M., El-Minir H. K., Riad A. M., "A Genetic Algorithm-Based, Dynamic Clustering Method Towards Improved WSN Longevity", J. Netw. Syst. Manag., Vol. 25, No.1, pp. 21-46, 2017.

[28] Ahuja H., Batra U., "Innovations in Computational Intelligence", Springer Press, Singapore, 2018.

[29] Syahputra R., "Distribution Network Optimization Based on Genetic Algorithm", J. Electr. Technol., Vol. 1, No.1, pp.19, 2017.

[30] Coley D., "An Introduction to Genetic Algorithm for Scientist and Engineers". World Scientific Publishing, USA, 1999. 